\title{
Flagellation of Certain Species of Pseudomonas as seen with the Electron Microscope
}

\author{
BY J. W. BARTHOLOMEW \\ Department of Bacteriology, University of Southern California, Los Angeles, \\ California
}

SUMMARY: The number and distribution of flagella on six species of Pseudomonas varied considerably for different cells of a culture. The flagellation reported for certain species of Pseudomonas in the sixth edition of Bergey is in error. A flagellum on a Pseudomonas cell might originate laterally or terminally. In some electron micrographs the flagellum was apparently inserted into the cell and attached to the cytoplasm. The diameter of the flagella varied greatly, and there was a tendency for certain of them to stick together in bundles. Some pictures showed evidence for the tubular nature of flagella, but this may have been an artefact. 'The terms monotrichate, lophotrichate, and amphitrichate are of little use as an aid in identifying a bacterial species, and bacteria should be classified as motile or non-motile, and if motile as possessing either peritrichate flagellation or with a tendency for terminal flagellation.

The electron microscope has been very useful to bacteriologists as a tool for the study of bacterial morphology, particularly in the study of bacterial flagellation. The techniques are simpler than the usual flagella staining methods, and the results are certainly as reliable. Often many more flagella are observed with the electron microscope than were previously reported by workers using the flagella staining techniques (see Hofer, 1944).

Two widely different methods are often used in electron microscope studies. One involves the use of the shadowing technique as outlined by Williams \& Wyckoff (1945). The other simply records electron-transmission and electronscattering of the object itself. The shadow technique has the advantage of giving the picture a third dimension and aids greatly in showing the actual three-dimensional shape of an object, or to detect superimposed objects such as flagella passing over the surface of the bacterial cell. The shadow technique has the disadvantage that internal structure of the cell is hidden except as it might appear as a bump or protrusion on the surface of the cell. The simpler technique of recording electron-transmission and scattering by the object has the advantage of actually recording the internal structure of the dried cell. There has recently been a great tendency to ignore the latter technique in the study of bacterial morphology. The present paper deals with the number and origin of flagella of certain Pseudomonas species. The shadow technique was not used, principally because the necessary equipment was not available at the time the work was done.

Previous studies on the flagellation of the genus Pseudomonas have used staining techniques. The reports have been confusing. Reid, Naghski, Farrell \& Haley (1942) reported that all of 27 strains of Pseudomonas which showed monotrichate flagellation belonged to the species aeruginosa, while 603 strains showing two or more flagella all belonged to the species fuorescens. Harris 
(1940) reported that of 30 monotrichate strains of Pseudomonas studied, most were $P$ s. aeruginosa and a few were Ps. fluorescens. The sixth edition of Bergey (1948) reports $P$ s. fluorescens as being motile, possessing a polar flagellum, and Ps. aeruginosa as possessing one to three polar flagella in one sentence, and as being monotrichate in the next sentence. This same confusion exists for many other motile species of bacteria. Extensive electron microscope studies are obviously necessary to clarify and extend our knowledge of bacterial flagellation.

\section{EXPERIMENTAL METHODS}

Table 1 lists the twelve strains of Pseudomonas spp. studied. The cultures were grown on nutrient agar slopes at $37^{\circ}$ for $48 \mathrm{hr}$. and suspended in distilled water. The suspension was diluted to give well-isolated cells on the slide. This was necessary because more than one cell in a low-power field made it difficult to determine the origin of a particular flagellum. During the preparation of the suspension care was taken not to agitate the cells unnecessarily, and thus to risk breaking flagella from the cells. Collodion slides were prepared by placing a drop of the dilute suspension on the collodion-covered screen, and after a few seconds shaking off the excess. The slide was then allowed to dry in air. A 50kV. RCA, EMU Model, electron microscope was used. Observations were made until variation in the number of flagella was demonstrated for each strain, or until it was felt that variation could not be demonstrated under the conditions of study.

\section{RESULTS AND DISCUSSION}

Table 1 presents the results obtained with the twelve strains of Pseudomonas. Six species were represented and in all except $\boldsymbol{P}$ s. denitrificans, the flagella varied from one to several per cell. This does not prove that Ps. denitrificans is always monotrichate, because other strains and conditions of cultivation were not studied. One strain of Ps. fluorescens seemed to be monotrichate, while other strains were lophotrichate. Comparison of these results with the type of flagellation recorded in Bergey (1948) shows that wherever Bergey's manual has made a specific statement, such as 'possessing a single polar flagellum', this study has shown the statement to be incorrect.

The members of the genus Pseudomonas are generally thought of as having terminal flagella. In this study flagella frequently appeared to originate on the sides of the cell, or even on opposite ends of the cell. Figs. 9, 10, 12, and 13 in Plates 2 and $\mathbf{3}$ show the origin of flagella over a wide area of the end of the cell. Two definitely lateral flagella can be seen in Pl. 3, fig. 13. Pl. 3, figs. 14, 15, show a single flagellum originating on the lateral part of the cell. One cell in Pl. 3, fig. 15, has a rather vague object coming from it which is probably not a flagellum. Pl. 3, fig. 16, shows two flagella originating from the lateral surface of the cell which join to form one large single flagellum. Pl. 2, figs. 7, 8, show an amphitrichate arrangement of the flagella. In Pl. 2, fig. 8, the flagella are thick, in that they measure $0.026 \mu$ in diameter, while those in Pl. 2, fig. 7, are very fine and measure only $0.016 \mu$ in diameter. Note also in Pl. 2, fig. 7, that two flagella appear to join to form one flagellum. In all of 
these pictures well-isolated cells are shown, and there is little chance that the flagella seen might originate from neighbouring cells. It is possible, however, that the lateral flagella in $\mathrm{Pl}$. 3, figs. 14, 15, might have originated on the end of the cell and fold under the cell to emerge on the side. The apparent

Table 1. Number of flagella observed on Pseudomonas

\begin{tabular}{|c|c|c|c|}
\hline \multirow[b]{2}{*}{ Organism } & \multirow{2}{*}{$\begin{array}{c}\text { Flagellation as reported in } \\
\text { Bergey (6th ed.) }\end{array}$} & \multicolumn{2}{|c|}{$\begin{array}{l}\text { Flagellation as observed } \\
\text { with electron microscope } \\
\text { (present work) }\end{array}$} \\
\hline & & No. of cells & Flagella/cell \\
\hline $\begin{array}{l}\text { Ps. ovalis } \\
\text { A.T.C. No. } 8209\end{array}$ & $\begin{array}{l}\text { Motile, possessing a single } \\
\text { polar flagellum }\end{array}$ & $\begin{array}{l}5 \\
4 \\
1 \\
1 \\
1\end{array}$ & $\begin{array}{l}1 \\
2 \\
4 \\
5 \\
6\end{array}$ \\
\hline $\begin{array}{l}\text { Ps. mildenbergii } \\
\text { A.T.C. No. } 795\end{array}$ & $\begin{array}{l}\text { Motile, possessing polar fla- } \\
\text { gella }\end{array}$ & $\begin{array}{l}6 \\
3 \\
1 \\
1 \\
1\end{array}$ & $\begin{array}{r}1 \\
4 \\
6 \\
7 \\
15\end{array}$ \\
\hline $\begin{array}{l}\text { Ps. denitrificans } \\
\text { A.T.C. No. } 8453\end{array}$ & Motile & 20 & 1 \\
\hline $\begin{array}{l}\text { Ps. putida } \\
\text { A.T.C. No. } 4359\end{array}$ & $\begin{array}{l}\text { Motile, possessing polar fla- } \\
\text { gella }\end{array}$ & $\begin{array}{r}11 \\
5 \\
1 \\
1 \\
1\end{array}$ & $\begin{array}{l}\mathbf{1} \\
\mathbf{2} \\
\mathbf{3} \\
\mathbf{5} \\
\mathbf{6}\end{array}$ \\
\hline $\begin{array}{l}\text { Ps. fluorescens } \\
\text { A.T.C. No. } 9721\end{array}$ & $\begin{array}{l}\text { Motile, possessing a polar } \\
\text { flagellum }\end{array}$ & 15 & 1 \\
\hline Stone $\mathbf{R} \mathbf{I}$ & & $\begin{array}{r}20 \\
4\end{array}$ & $\begin{array}{l}\mathbf{1} \\
\mathbf{2}\end{array}$ \\
\hline U.S.C. & & $\begin{array}{r}14 \\
2 \\
1\end{array}$ & $\begin{array}{l}1 \\
2 \\
6\end{array}$ \\
\hline $\begin{array}{l}\text { Ps. aeruginosa } \\
\text { Stone } 96 b\end{array}$ & $\begin{array}{l}1 \text { to } 3 \text { polar flagella } \\
\text { Monotrichous (Reid, et al.) }\end{array}$ & $\begin{array}{l}30 \\
5 *\end{array}$ & $\begin{array}{l}1 \\
2\end{array}$ \\
\hline Stone $41 a$ & & 11 & 1 \\
\hline U.S.C. 46 & & 6 & 1 \\
\hline U.S.C. A 1 & & $\begin{array}{l}\mathbf{5} \\
\mathbf{1}\end{array}$ & $\begin{array}{l}1 \\
3\end{array}$ \\
\hline U.S.C. B1 & & $\begin{array}{l}7 \\
2 \\
1\end{array}$ & $\begin{array}{l}\mathbf{1} \\
\mathbf{2} \\
\mathbf{3}\end{array}$ \\
\hline & $\begin{array}{l}\text { y numerous 'pseudo' flagella. } \\
=\text { American Type Culture. } \\
=\text { R. W. Stone, Penn. State Un } \\
\text { University of Southern Calif }\end{array}$ & a. & \\
\hline
\end{tabular}

lateral origin of a flagellum was frequent, and of 220 flagellated cells twenty-one had lateral flagella. This indicates that the origin of flagella for various species of the genus Pseudomonas might not be restricted to the terminal area of the cell or only to one end of the cell. 
Pl. 2, fig. 6, shows many small flagella-like structures originating from the end of the cell opposite the end with a large flagellum. These structures were very common on the cells from Ps. aeruginosa strain $96 b$. On observing this culture in a hanging drop preparation, it was found that this strain possessed a remarkably high degree of motility. Pls. 1, 2, figs. 4, 5, show more of these fine flagella-like structures. Their origin appeared to be at any point on the cell.

The demonstration for the genus Pseudomonas of the lateral origin of flagella, the amphitrichate flagellation, and the fine flagella-like structures occurring almost anywhere on the cell, is compatible with the 'flagella degeneration' theory of Conn et al. (1920, 1938, 1940, 1947). Conn has stated that perhaps all motile bacterial cells were at one time peritrichate; hence, a monotrichate or lophotrichate cell has merely lost the ability to produce flagella in certain areas. Thus, any area of the cell might possess the ability to produce a flagellum. This theory might also explain the fine flagella-like structures seen in Ps. aeruginosa $96 \mathrm{~b}$, in that they might represent 'degenerate' flagella; but this is pure speculation. The present paper does not attempt to prove these structures to be flagella. There is some possibility that they might represent 'Pseudoflagella', as described by Thjøtta \& Kåss (1946), in which case they might be simply strung-out capsular material. Supporting evidence that they might be flagella consisted of the extremely high motility of the cells of this culture, as compared with the cells of other Pseudomonas cultures which did not show these structures.

The variation in numbers and distribution of flagella, as reported above, throws doubt on the usefulness of such terms as monotrichate, lophotrichate and amphitrichate, when these terms are used to aid in the classification. It would seem best simply to refer to bacteria as being motile or non-motile; and if motile, as possessing either peritrichate flagellation or a tendency toward terminal flagellation.

Pl. 1, figs. 1, 2, 3, show an apparent origin of the flagellum from the inner cytoplasm of the cell. The flagellum can be seen apparently to penetrate through the cell-wall, and then to expand into a broad base as it joins with the cytoplasm. This observation was made on only a few of the cells. The fact that this insertion could not be seen for all flagella is explicable on the basis of the drying effect of the electron microscope which causes the cytoplasm to retract from the cell-wall and the flagella to break away from it. Sometimes, by luck, the insertion remained intact. Recently van Iterson (1947) has published electron micrographs using the shadow-cast technique, which appear clearly to show a similar internal origin of flagella for Vibrio metchnikovii and Spirillum serpens. However, in both the pictures presented in the present paper, and in the pictures presented by van Iterson, there is the possibility that the flagella are merely underlying the cell-wall and that they really originate from the outer part of the cell; thus the apparent internal origin would be an artefact. Johnson, Zworykin \& Warren (1943) presented electron microscope evidence to show that bacterial flagella did penetrate through the cell-wall. They showed that cytoplasm of certain cells of Achromobacter spp. had flagella attached even 
though the cell-wall had apparently been removed. They also found, however, fragments of cell-wall, devoid of cytoplasm, with attached flagella. They proposed a theory that flagella might be composed of elements from both the cellwall and the cytoplasm. Leifson (1931) also presented some evidence, not obtained by the electron microscope, which seems to rule out the capsular origin of flagella in the manner proposed by Pijper (1947). Leifson showed that flagella appeared and began to grow in length while the spores of Bacillus cereus, B. vulgaris and B. flavus were in the early stage of germination and before the cell had acquired much, if any, motility. It could be that confusion is occurring simply because Pijper generalized observations based on a single species of bacteria.

Pl. 3, fig. 11, shows a flagellum which has split into two smaller flagella, Pl. 2, figs. 9, 10, show bundles of flagella which split into many smaller units. Practically every publication with electron microscope pictures of motile bacteria has shown the existence of 'split' flagella. Obviously, bacterial flagella tend to stick together when they are in juxtaposition. Pl. 2, figs. 7, 8, as commented upon earlier, obviously show the existence of flagella of different thicknesses. These flagella, as far as could be determined, were single flagella. The observation of variable thickness, and the sticking together of flagella, is in agreement with the observations of Johnson, Zworykin \& Warren (1943) in their studies of the flagellation of cells of luminous bacteria.

Pls. 1, 2, figs. 4, 5, show a surprising indication of structure for a flagellum. The pictures suggest either a tubular structure, or two flagella held together by a fine sheath. The existence of tubular structure in bacterial flagella is a matter of considerable debate. Polevitsky (1941) reported the apparent tubular structure of flagella in her electron microscope study of several unnamed genera of bacteria. Mudd \& Anderson (1942) made similar observations for Eberthella typhosa treated with $0.59 \mathrm{~m}$ lead acetate. However, they believed the appearances to be artefacts and the structure to be due to the accumulation of dissolved protoplasmic components along the sides of the flagella during the drying of the preparation. This contention was supported by the observation that the tubular structure occurred only in the areas adjacent to what were termed 'lysed' cells. The same flagellum would appear tubular near the cell, but structureless at a distance from the cell. It is possible, however, to interpret their pictures differently; in the area adjacent to the cell the lead acetate might be in higher concentrations, and this, as shown in an earlier section of their paper, might increase contrast so as to make the tubular structure appear. The cells pictured in the present paper were in no way treated; nevertheless the tubular structure appears throughout the length of the flagellum, and the background is clear. Moreover, if the dark edges were due to accumulated dirt, then this line might also be expected to occur along the edge of the cell-wall; but this was not so. It is also possible that the double structure could be two small flagella lying parallel and held together by a thin sheath. The joining of two flagella in Pl. 3, fig. 16, lends support to this explanation, but it seems improbable, since many 'tubular' flagella were seen with no indication of the joining of two flagella at the base. The exact interpretation of 
this appearance, then, is in doubt, and the necessity for more work along these lines is strongly indicated.

The author is indebted to Dr Daniel C. Pease and Dr R. F. Baker, of the School of Medicine, University of Southern California, for instruction and assistance in the operation of the electron microscope. Dr R. W. Stone of Pennsylvania State University very kindly provided several of the Pseudomonas strains studied.

\section{REFERENCES}

Bergey, D. H. (1948). (Edited by R. S. Breed, E. G. D. Murray \& A. P. Hitchens.) Manual of Determinative Bacteriology, 6th ed. Baltimore, Md., U.S.A.: The Williams and Wilkins Co.

ConN, H. D. \& Breed, R. S. (1920). A suggestion as to the flagellation of the organisms causing legume nodules. Science, $51,391$.

ConN, H. J. \& Elrod, R. P. (1947). Concerning flagellation and motility. J. Bact. $54,681$.

Conn, H. J. \& Wolfe, S. D. (1938). The flagellation of bacteria. Science, 87, 283.

Conn, H. J., Wolfe, S. E. \& Ford, M. (1940). 'Taxonomic relationships of Alcaligenes spp. to certain soil saprophytes and plant parasites. J. Bact. 39, 207.

Harris, R. G. (1940). A study of thirty monotrichic strains of Pseudomonas. $J$. Bact. 39, 91.

Hofer, A. W. (1944). Flagellation of Azotobacter. J. Bact. 48, 697.

ITERSON, W. VAN (1947). Some electron-microscopical observations on bacterial cytology. Biochim. Biophys. Acta, 1, 527.

Johnson, F. H., Zworykin, N. \& Warren, G. (1943). A study of luminous bacterial cells and cytolysates with the electron microscope. J. Bact. 46, 167.

Leifson, Einar (1931). Development of flagella on germinating spores. J. Bact. 21, 357.

Mudd, S. \& Anderson, T. F. (1942). Selective 'staining' for electron micrography. The effects of heavy metal salts on individual bacterial cells. J. exp. Med. 76, 103 .

PiJPer, A. (1947). Methylcellulose and bacterial motility. J. Bact. 53, 257.

Polevitsky, K. (1941). Pictures of bacterial forms taken with the electron microscope. J. Bact. 41, 260.

Reid, J. J., Naghski, J., Farrell, M. A. \& Haley, D. E. (1942). Bacterial leafspots of Pennsylvania tobacco. I. Occurrence and nature of the microorganism associated with wildfire. Bull. Pa agric. Exp. Sta. no. 422.

Thuøtтa, Th. \& KÅss, E. (1946). Pseudo-flagella in bacteria. Acta path. microbiol. scand. 23, 215.

Williams, R. C. \& WyскоF, R. W. G. (1945). Shadowed electron micrographs of bacteria. Proc. Soc. exp. Biol., N.Y., 59, 256.

\section{EXPLANATION OF PLATES}

\section{Plate 1}

Fig. 1. Ps. aeruginosa $(96 \mathrm{~b})$. Showing apparent origin of a flagellum from inside of cell. $\times 82,000$.

Fig. 2. Ps. aeruginosa (96b). Showing apparent origin of a flagellum from inside of cell. $\times 130,000$.

Fig. 3. Ps. denitrificans (A.T.C. No. 8453). Showing apparent origin of a flagellum from inside of cell. $\times 95,000$.

Fig. 4. Ps. aeruginosa (96b). Showing apparent tube-like structure of large flagella, also very fine flagella-like strands. $\times 120,000$. 


\section{Plate 2}

Fig. 5. Ps. aeruginosa (96b). Showing apparent tube-like structure of large flagella, also very fine flagella-like strands. $\times 52,000$.

Fig. 6. Ps. aeruginosa (96b). Showing many fine flagella-like structures on one end of cell. $\times 30,000$.

Fig. 7. Ps. aeruginosa (U.S.C. A1). Showing amphitrichate arrangement of flagella. $\times 38,000$.

Fig. 8. Ps. putida (A.T.C. No. 4359). Showing amphitrichate arrangement of flagella. $\times 38,000$.

Fig. 9. Ps. mildenbergii (A.T.C. No. 795). Showing a bundle of flagella splitting into separate units. $\times 42,000$.

Fig. 10. Ps. mildenbergii (A.T.C. No. 795). Showing the splitting of bundles of fiagella into separate units. $\times 52,000$.

\section{Plate 3}

Fig. 11. Ps. aeruginosa (U.S.C. A 1). Showing split flagellum, also cell vacuole. $\times 28,000$.

Fig. 12. Ps. putida (A.T.C. No. 4359). Showing the origin of flagella over a wide area on the end of a cell. $\times 38,000$.

Fig. 13. Ps. mildenbergii (A.T.C. No. 795). Showing lateral origin of flagella. $\times 32,000$.

Fig. 14. Ps. aeruginosa $(96 \mathrm{~b})$. Showing lateral origin of a flagellum. $\times 34,000$.

Fig. 15. Ps. aeruginosa (96b). Showing lateral origin of a flagellum. $\times 38,000$.

Fig. 16. Ps, mildenbergii (A.T.C. No. 795). Showing lateral flagella uniting to form one flagellum. $\times 34,000$. 
Journal of General Microbiology, Vol. 3, No. 3
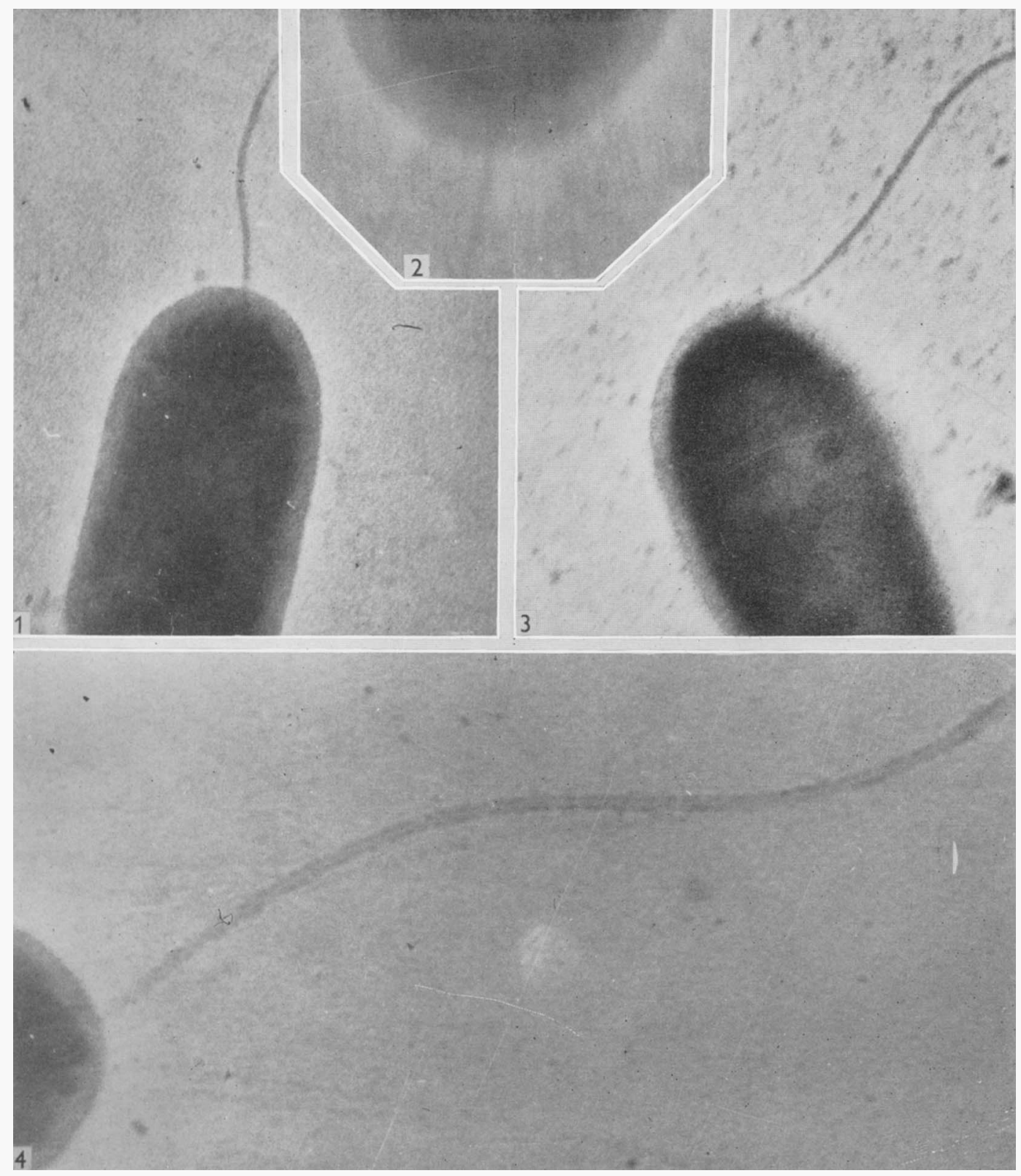

Figs. 1-4

J. W. Bartholomew - Flagellation of Pseudomonas. Plate 1 
Journal of General Microbiology, Vol. 3, No. 3
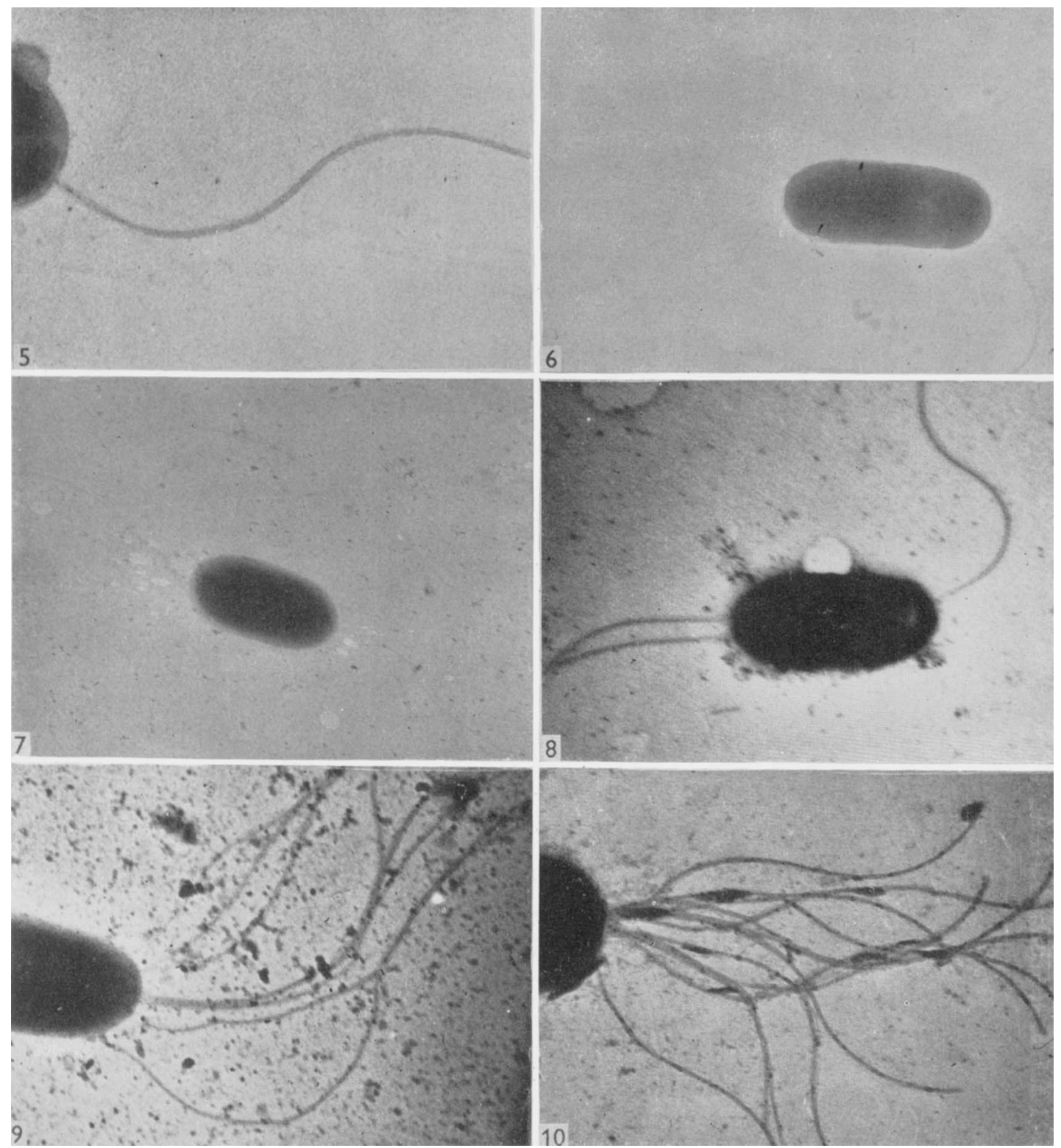

Figs. 5-10

J. W. Bartholomew-Fingelation of Psevdomonas. Piate 2 
Journal of General Microbiology, Vol. 3, No. 3
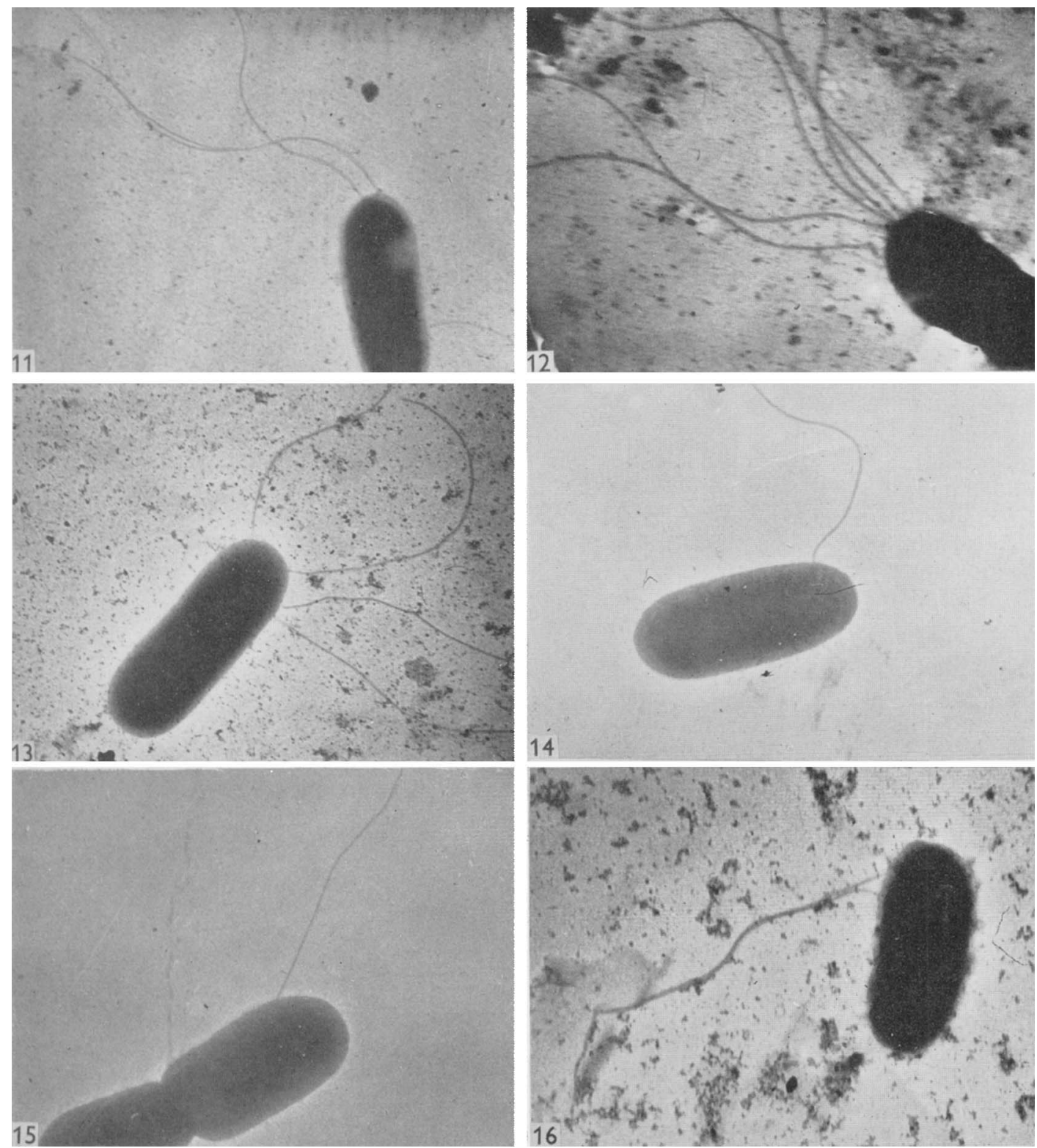

Figs. 11-16

J. W. Bartholomiw- Fiaglalation of Psuudomonas. Prate 3 